\title{
The inhibition of acrosin by sterol sulphates
}

\author{
P. J. Burck and R. E. Zimmerman \\ Biochemical Research Department, Lilly Research Laboratories, Indianapolis, Indiana 46206, \\ U.S.A.
}

\begin{abstract}
Summary. Four $3 \beta$-hydroxy- $\Delta^{5}$-steroid sulphates were found to be potent and specific inhibitors of the sperm acrosomal proteinase, acrosin. Two of these acrosin inhibitors, desmosteryl sulphate and cholesteryl sulphate, occur naturally in spermatozoa. Desmosteryl sulphate, an inhibitor of the in-vitro capacitation of hamster spermatozoa, has a $K_{\mathrm{i}}$ of $3.5 \times 10^{-6} \mathrm{M}$ for the inhibition of acrosin. The mechanism of inhibition of sperm capacitation by sterol sulphates is probably due to their inhibition of acrosin.
\end{abstract}

\section{Introduction}

Sterol sulphates have been isolated from a variety of mammalian tissues and body fluids (Roberts \& Lieberman, 1970) since the initial isolation of cholesteryl sulphate from bovine adrenals (Drayer, Roberts \& Lieberman, 1964). Desmosteryl sulphate has been isolated from hamster epididymal spermatozoa (Bleau \& VandenHeuvel, 1974), and cholesteryl sulphate has been identified as the primary sterol sulphate component of human spermatozoa (Lalumière, Bleau, Chapdelaine \& Roberts, 1976). Desmosteryl sulphate was an extremely potent inhibitor of the in-vitro capacitation of hamster spermatozoa by cumulus cells but had no effect on sperm penetration of the eggs once capacitation had occurred (Bleau, VandenHeuvel, Andersen \& Gwatkin, 1975).

Meizel \& Mukerji (1975) have proposed that one of the events of sperm capacitation is the activation of proacrosin to acrosin (EC 3.4.21.10), the sperm acrosomal proteinase responsible for penetration of the zona pellucida of the egg (Stambaugh \& Buckley, 1969). Meizel \& Lui (1976) have also suggested that a trypsin-like enzyme, probably acrosin, may play a role in the acrosome reaction, because several inhibitors of trypsin and acrosin blocked the acrosome reaction of hamster spermatozoa in vitro. The ionophore A23187 induces a normal acrosome reaction in guinea-pig spermatozoa and results in the liberation of acrosin activity from the acrosomal contents. In the presence of synthetic trypsin and acrosin inhibitors, however, the membrane fusion associated with the acrosome reaction proceeds normally, but the release of acrosin activity is inhibited (Green, 1978).

We have investigated whether the mode of inhibition of hamster sperm capacitation by desmosteryl sulphate described by Bleau et al. (1975) might be due to the inhibition of acrosin.

\section{Materials and Methods}

Acrosin was isolated from washed, ejaculated boar spermatozoa by the extraction procedure of Srivastava (1973). The extract was acidified and further purified by gel filtration on Sephadex G50F and G100 columns equilibrated at $5^{\circ} \mathrm{C}$ with $0.01 \mathrm{~N}-\mathrm{HCl}$. Final purification was achieved by affinity chromatography of the acrosin on a column of $p$-aminobenzamidine bound to $\mathrm{CH}$ Sepharose, using a modification of the method described by Schleuning, Schiessler \& Fritz (1973). Units of acrosin and acrosin inhibitor activity using $N$ - $\alpha$-benzoyl-DL-arginine- $p$-nitro- 
anilide $\mathrm{HCl}$ (BAPNA) as the substrate are expressed using the method of Fritz, Hartwich \& Werle (1966). Inhibition of the hydrolysis of $N$ - $\alpha$-p-tosyl-L-arginine methyl ester HCl (TAME) by various enzymes is expressed using the method of Hummel (1959). All spectrophotometric assays were performed at $25^{\circ} \mathrm{C}$ using a Gilford 240 recording spectrophotometer. One unit of acrosin activity is defined as the amount of enzyme catalysing the hydrolysis of $1 \mu \mathrm{mol}$ BAPNA or TAME per min at $25^{\circ} \mathrm{C}$ in $0.05 \mathrm{M}$-triethanolamine, $\mathrm{pH} \mathrm{7.8.} \mathrm{A} \mathrm{molar} \mathrm{extinction} \mathrm{coefficient} \mathrm{of}$ $9950 \mathrm{M}^{-1} \mathrm{~cm}^{-1}$ was used to determine reaction velocities when BAPNA was used as the substrate. A value of $540 \mathrm{M}^{-1} \mathrm{~cm}^{-1}$ was used for TAME. One acrosin inhibitor unit decreases the activity of two acrosin units by $50 \%$, i.e. reduces the substrate turnover by $1 \mu \mathrm{mol} / \mathrm{min}$. Acrosin with a specific activity of $13.0 \pm 0.5$ units $/ \mathrm{mg}$ in the BAPNA assay was used for all acrosin inhibitor studies. Disc gel electrophoresis of this acrosin at $\mathrm{pH} 4.5$ in a $10 \%$ gel indicated one major band and a faint trailing minor band, while only one band was observed in SDS gels at $\mathrm{pH}$ 8.9. Crystalline porcine pancreatic trypsin (Novo), plasmin (Michigan Department of Health) and thrombin (Parke-Davis Topical) were used to assay the inhibition of these enzymes by sterol sulphates.

The pyridinium sulphates of crystalline desmosterol $(5,24$-cholestadien-3 $\beta$-ol), cholesterol ( 5 cholesten-3 $\beta$-ol), campesterol (5-cholesten-24b-methyl-3 $\beta$-ol), and $\beta$-sitosterol (5-cholesten-24bethyl-3 $\beta$-ol) were prepared using pyridine sulphur trioxide (Sobel \& Spoerri, 1941). The sterol sulphate pyridinium salts were recrystallized to a constant melting point which agreed with literature values. These sterol sulphate preparations exhibited homogeneity when fresh methanolic solutions were chromatographed on silica gel plates by the thin-layer chromatography solvent systems described by Bleau \& VandenHeuvel (1974). $\beta$-Sitosteryl pyridinium sulphate was converted to the potassium salt by the method of Sobel \& Spoerri (1941).

Rabbit eggs were used to measure the inhibition of zona pellucida dissolution by acrosin (Stambaugh \& Buckley, 1969). Six rabbit ova were incubated in $120 \mu \mathrm{Ca}^{++}$-free Ringer's solution for each measurement.

\section{Results}

All four of the $3 \beta$-hydroxy- $\Delta^{5}$ steroid sulphate pyridinium salts were found to be extremely potent inhibitors of acrosin amidase activity when BAPNA was the substrate (Table 1). The corresponding free sterols and pyridine sulphur trioxide did not inhibit acrosin. The inhibition

Table 1. The inhibition of boar acrosin by sterol sulphates

\begin{tabular}{lc}
\hline \multicolumn{1}{c}{ Compound } & Inhibition (units $/ \mathrm{mg}$ ) \\
\hline Desmosteryl sulphate pyridinium salt & $13 \cdot 6$ \\
Cholesteryl sulphate pyridinium salt & $15 \cdot 1$ \\
Campesteryl sulphate pyridinium salt & $18 \cdot 1$ \\
$\beta$-Sitosteryl sulphate pyridinium salt & $18 \cdot 1$ \\
$\beta$-Sitosteryl sulphate potassium salt & $18 \cdot 2$ \\
$p$-Aminobenzamidine HCl & $4 \cdot 8$ \\
Desmosterol & 0 \\
Pyridine sulphur trioxide & 0 \\
\hline
\end{tabular}

Table 2. Inhibition of serine proteases by sterol sulphates

\begin{tabular}{lcccc}
\hline \multicolumn{1}{c}{ Compound } & Acrosin & Trypsin & Plasmin & Thrombin \\
\hline Desmosteryl sulphate & 250 & $2 \cdot 2$ & $3 \cdot 3$ & $1 \cdot 1$ \\
Cholesteryl sulphate & 310 & 0 & $2 \cdot 2$ & $1 \cdot 1$ \\
\hline
\end{tabular}


seen in the same assay system with $p$-aminobenzamidine $\mathrm{HCl}$, a known competitive inhibitor of acrosin and trypsin, is included for comparison. The potassium salt of $\beta$-sitosteryl sulphate was as effective as the pyridinium salt as an acrosin inhibitor.

The $3 \beta$-hydroxy- $\Delta^{3}$ steroid sulphates are not only very potent acrosin inhibitors, but are also quite specific. Table 2 shows the inhibitory spectrum of desmosteryl and cholesteryl sulphate pyridinium salts against various serine proteases using TAME as the substrate. A double reciprocal plot of the inhibition of boar sperm acrosin by desmosteryl sulphate (Text-fig. 1) indicates that this compound is a competitive inhibitor of acrosin. A Dixon plot of these data (Text-fig. 2) gives the $K_{\mathrm{i}}$ for this inhibition as $3.5 \times 10^{-6} \mathrm{M}$.

When cumulus-free rabbit eggs were incubated with 0.15 units (BAPNA assay) boar sperm acrosin for $70 \mathrm{~min}$ at $37^{\circ} \mathrm{C}$, the zonae pellucidae were completely removed from the eggs. However, when $50 \mu \mathrm{g}$ of each of the four sterol sulphates were included in the incubation mixture, the zonae pellucidae were still intact at the end of the incubation period.

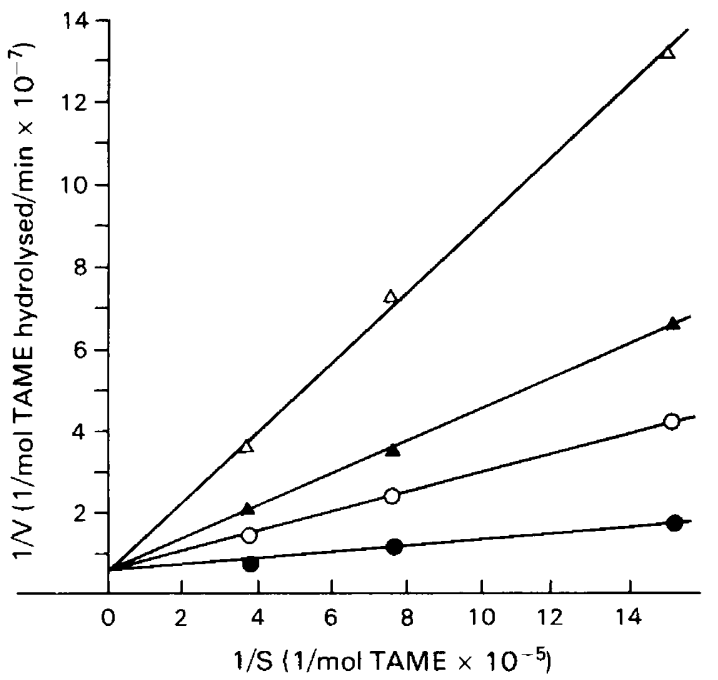

Text-fig. 1. Lineweaver-Burk plot of the inhibition of boar acrosin by desmosteryl sulphate $(O$, $\left.0.61 \times 10^{-6} \mathrm{M} ; \Delta, 1.23 \times 10^{-6} \mathrm{M} ; \Delta, 3.07 \times 10^{-6} \mathrm{M}\right)$.

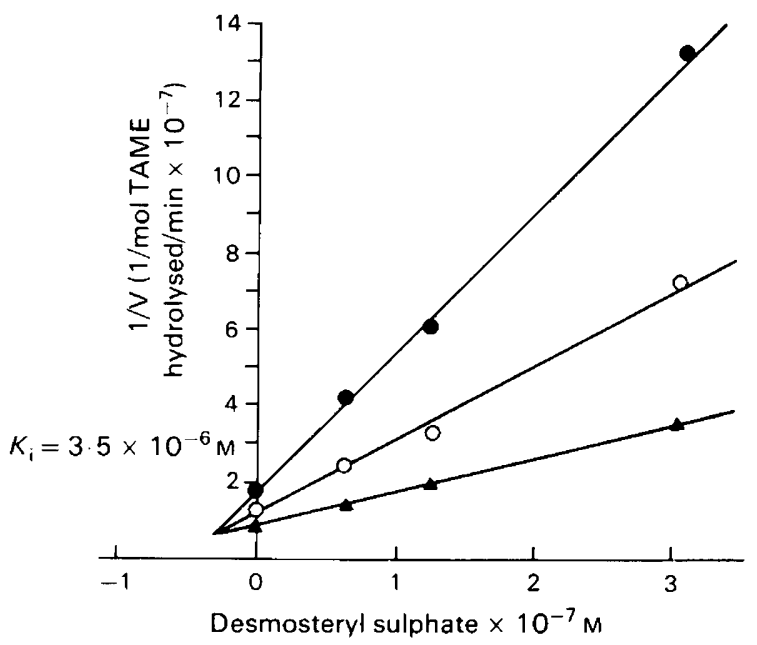

Text-fig. 2. Dixon plot of the inhibition of boar acrosin by desmosteryl sulphate $\left(\Delta, 2.64 \times 10^{-6}\right.$ M-TAME; $0,1.32 \times 10^{-6} \mathrm{M}$-TAME; $0.66 \times 10^{-6} \mathrm{M}$-TAME). 


\section{Discussion}

This preliminary investigation indicates that desmosteryl and cholesteryl sulphates, naturally occurring components of hamster and human spermatozoa, are potent and specific inhibitors of the sperm acrosomal proteinase, acrosin. The sulphates of the plant sterols, campesterol and $\beta$ sitosterol, were similarly inhibitory. This inhibition has been conclusively demonstrated by inhibiting acrosin BAPNA amidase activity, TAME esterase activity, and the acrosin-mediated dissolution of the zona pellucida of rabbit ova.

The inhibition of in-vitro capacitation observed by Bleau et al. (1975) can be explained by our observation that desmosteryl sulphate is a potent inhibitor of acrosin. The time course of inhibition in the experiments of Bleau et al. (1975) argues against the direct inhibition by desmosteryl sulphate of the acrosin-mediated penetration of the zona pellucida by hamster spermatozoa. However, the concentration of desmosteryl sulphate $\left(10^{-9} \mathrm{M}\right)$ used by Bleau et al. (1975) in the ovum penetration studies may not have been high enough to inhibit all the active acrosin of the capacitated spermatozoa. It is more likely that desmosteryl sulphate inhibited sperm capacitation by one of the following mechanisms. (1) It completely inhibited the induction of the acrosome reaction. Meizel \& Lui (1976) observed that the acrosin inhibitors 1-chloro-3tosylamido-7-amino-2-heptanone $\mathrm{HCl}$ (TLCK), p-nitrophenyl-p'-guanidinobenzoate $\mathrm{HCl}$ (NPGB), and benzamidine $\mathrm{HCl}$ inhibited the induction of the acrosome reaction in unwashed hamster spermatozoa. More recently Lui \& Meizel (1979) used these same acrosin inhibitors to inhibit the acrosome reaction of washed hamster epididymal spermatozoa induced by the calcium ionophore A23187. (2) It delayed the acrosome reaction in the same manner observed by Green (1978) with guinea-pig spermatozoa and the acrosin inhibitors benzamidine $\mathrm{HCl}$, and $p$-aminobenzamidine $\mathrm{HCl}$. The ionophore $\mathrm{A} 23187$ induced an acrosome reaction in the majority of the spermatozoa in $5 \mathrm{~min}$. In the presence of $100 \mu \mathrm{M}$-benzamidine $\mathrm{HCl}$ or $p$ aminobenzamidine $\mathrm{HCl}$ about $15 \mathrm{~min}$ was required for the majority of the spermatozoa to undergo the acrosome reaction. (3) It inhibited the activation of proacrosin and the subsequent release of free acrosin following the membrane fusion associated with the acrosome reaction (Green, 1978). Further work will be necessary to determine which of these three possibilities is correct.

We would agree with the suggestion of Lalumière et al. (1976) that a sterol sulphatase present in the female reproductive tract could hydrolyse the endogenous sterol sulphates found in the acrosomal region of mammalian spermatozoa, thereby allowing capacitation to proceed. These authors suggest that the sulphatase is removing a potential stabilizing factor from sperm membranes, since sterol sulphates have been shown to stabilize human erythrocytes (Bleau, Bodley, Longpre, Chapdelaine \& Roberts, 1974). However, we would propose that capacitation occurs because the sterol sulphatase has removed a potent and specific acrosin inhibitor from the sperm acrosome.

\section{References}

Bleau, G. \& VandenHeuvel, W.J.A. (1974) Desmosteryl sulfate and desmosterol in hamster epididymal spermatozoa. Steroids 24, 549-556.

Bleau, G., Bodley, F.H., Longprè, J., Chapdelaine, A. \& Roberts, K.D. (1974) Cholesterol sulfate, occurrence and possible function as an amphipathic lipid in the membrane of the human erythrocyte. Biochim. Biophys. Acta 352, 1-9.

Bleau, G., VandenHeuvel, W.J.A., Andersen, O.F. \& Gwatkin, R.B.L. (1975) Desmosteryl sulphate of hamster spermatozoa, a potent inhibitor of capacitation in vitro. J. Reprod. Fert. 43, 175-178.
Drayer, N.M., Roberts, K.D. \& Lieberman, S. (1964) The isolation of cholesterol sulfate from bovine adrenals. J. biol. Chem. 239, PC3112-3114.

Fritz, H., Hartwich, G. \& Werle, E. (1966) Über proteasinhibitoren I. Isolierung und charakterisierung des trypsininhibitors aus pankreasgewebe und pankreassekret vom hund. Hoppe-Seyler's Z. Physiol. Chem. 345, 150-167.

Green, D.P.L. (1978) The activation of proteolysis in the acrosome reaction of guinea-pig sperm. J. Cell Sci. 32, $153-164$.

Hummel, B.C.W. (1959) A modified spectrophotometric 
determination of chymotrypsin, trypsin, and thrombin. Can. J. Biochem. Physiol. 37, 1393-1399.

Lalumière, G., Bleau, G., Chapdelaine, A. \& Roberts, K.D. (1976) Cholesteryl sulfate and sterol sulfatase in the human reproductive tract. Steroids 27, 247-260.

Lui, C.W. \& Meizel, S. (1979) Further evidence in support of a role for hamster sperm hydrolytic enzymes in the acrosome reaction. J. exp. Zool. 207, $173-188$.

Meizel, S. \& Lui, C.W. (1976) Evidence for the role of a trypsin-like enzyme in the hamster sperm acrosome reaction. J. exp. Zool. 195, 137-144.

Meizel, S. \& Mukerji, S.K. (1975) Proacrosin from the rabbit epididymal spermatozoa: partial purification and initial biochemical characterization. Biol. Reprod. 13, 83-93.

Roberts, K.D. \& Lieberman, S. (1970) The biochemistry of the $3 \beta$-hydroxy- $\Delta^{5}$ steroid sulfates. In Chemical and Biological Aspects of 'Steroid Conjugation, pp. 219-290. Eds S. Solomon \& S. Berstein. SpringerVerlag, New York.

Schleuning, W.D., Schiessler, H. \& Fritz, H. (1973) Highly purified acrosomal proteinase (boar acrosin): isolation by affinity chromatogrpahy using benzamidine-cellulose and stabilization. HoppeSeyler's Z. Physiol. Chem. 354, 550-554.

Sobel, A.E. \& Spoerri, P.E. (1941) Steryl sulfates. I. Preparation and properties. J. Am. Chem. Soc. 63, 1259-1261.

Srivastava, P.N. (1973) Removal of acrosomes of ram and rabbit spermatozoa. $J$. Reprod. Fert. 33, 323326.

Stambaugh, R. \& Buckley, J. (1969) Identification and subcellular localization of the enzymes effecting penetration of the zona pellucida by rabbit spermatozoa. J. Reprod. Fert. 19, 423-432.

Received 4 April 1979 